\title{
The Scales in the Leipzig Mahzor
}

\section{Penance and Eschatology in Early Fourteenth-Century Germany* \\ Katrin Kogman-Appel}

In the Middle Ages the Jewish liturgical cycle began in spring with the first special Sabbath. As typical of the yotser genre, ${ }^{1}$ the yotser for that day refers repeatedly to the Pentateuch portion (Parashat Shekalim: Ex. 30:11-16) to be read in addition to the regular Sabbath pericope during the morning service. The biblical text describes the Israelites giving money, shekalim, to build the desert Tabernacle.

In accord with a common custom that developed in the mid-thirteenth century for the design of festival prayer books, mahzorim, it was this type of liturgical poem, the yotsrot, the poetic embellishments of the Shema Israel prayer, that received most of the artistic decoration, normally in the form of initial panels. As the mahzor contains only the poetic embellishments, but not the regular prayer, it is with these initial panels of the yotsrot that the liturgy of a new holiday is begun. ${ }^{2}$ This is also the case in most sections of the so-called Leipzig Mahzor, ${ }^{3}$ where for Parashat Shekalim

* An earlier version of this paper was delivered at the Fourteenth World Congress of Jewish Studies, August 2005.

1 Davidson (1924), vol. 1, 178, no. 3853.

2 As observed by Shalev-Eyni (2001), 53, for the so-called Tripartite Mahzor; this system was often pursued, even though not religiously.

3 Leipzig, Universitätsbibliothek, MS Vollers 1102/I-II; for a facsimile edition of the illuminations, see Katz (1964); for a CD-ROM version see Mackert. In the liturgy of Parashat Shekalim, it is indeed only the yotser that is decorated; on other occasions, however, we also find other types of piyyutim embellished; see Shalev-Eyni (2001), 58, n. 30. 
the opening word "El" of the yotser is decorated with a large panel containing four medallions of the eschatological creatures (Ezek. 1:4-25) and a balance surrounded by two dragons in the center of the composition (Fig. 1). In the upper margin a small hunting motif - a hare and a dog — can be discerned. The Leipzig Mahzor, written and illuminated around 1310 in southern Germany, is a two-volume prayer book and one of the most elaborately decorated extant Ashkenazic mahzor manuscripts. ${ }^{4}$

Parashat Shekalim describes how the Israelites gave half a shekel each for the Tabernacle. Actual weighing of the shekalim is not mentioned explicitly. The text uses various forms of the root kaph-pe-resh. In verse 12: "Each man is to give a ransom for his life to the Lord (kofer nafsho le'adonai), to avert plague among them during the registration.” In verse 15: “...when you give the contribution for the Lord to make expiation for your lives (lekhapper al nafshotechem)." In verse 16: “The money received from the Israelites for expiation (kesseph hakippurim) you are to apply to the service of the Tent of Meeting." In short, each man gives his ransom, which promises expiation - atonement. Similarly, the decorated liturgical poem

4 The Leipzig Mahzor has no colophon and its dating relied hitherto on stylistic considerations; an upper Rhenish provenance was suggested by Voller (1906), vol. 2, 437, no. 1102; followed later by Katz in his commentary volume, Katz (1964), 14-15, and Narkiss's contribution in the same volume, 47; see also Sed-Rajna (1983), 16; C. Mackert in personal conversations and in a lecture he gave in Leipzig in 2005. I am indebted to Dr. Mackert for sharing the manuscript of his paper with me. In a later publication Narkiss locates the Leipzig Mahzor more generally in southern Germany, Narkiss (1984), 21. Recently Raeber (2003), 117-121, suggested a provenance in Freiburg im Breisgau . Elsewhere I shall revisit the question of its origin by examining its text version, which seems to point to the middle Rhine region; K. Kogman-Appel, The Leipzig Mahzor: Art and Society in Medieval Ashkenazic Culture (in prep.), chap. 1. 
creates a connection between the ransom and atonement for the sins, which is the main theme in its second section. The first part, however, ends with an allusion to the divine Throne of Glory as it is described in the first chapter of the Book of Ezekiel (Ezek. 1:26-28).

The imagery on the Leipzig initial panel, ${ }^{5}$ which has no parallel and does not follow any established iconographical tradition, addresses all the aspects mentioned in both the biblical and the liturgical texts. The balance refers to the contributions of the Israelites. In an interpretation of this biblical event it is naturally assumed that the money collected for the Tabernacle was weighed. But the scales are also a common symbol for the atonement of sins. The balance is, finally, surrounded by medallions displaying the four creatures mentioned in the Ezekiel vision. In some sense, it is God who holds the scales, which are balanced and even; they are attached to the upper frame by a hook and the vertical pole lies on the lamed of the aleph-lamed ligature standing for $E l$, God.

Earlier research paid very little attention to this unusual setting, which, at first sight, seems to be entirely indebted to Christian art. ${ }^{6}$ Both elements play an important role in Christian eschatological iconography: the four creatures, understood as

5 An illustration of the Shekalim pericope and the related yotser is also found in the Worms Mahzor, Jerusalem, Jewish National and University Library, MS 40781/1, Würzburg (?), 1272-73; for a facsimile edition, see Beit-Arié (1986); it shows the figure of a man with scales, with the heavy side inscribed "Israel."

6 See, e.g., Wischnitzer (1960), 23-25, who linked the medallions to Ezekiel and representations of the Evangelists, and the scales to the money changers in the Second Temple; on the relation to Christian sources, see also Narkiss's contribution in Katz (1964), 31. 
symbols of the Evangelists, are associated with the Second Coming of Christ (Fig. 2), and the scales are prominent in depictions of the Last Judgment (Fig. 3). ${ }^{7}$ The Leipzig image was thus understood as an eschatological weighing of the souls modeled after Christian representations of the Last Judgment. ${ }^{8}$ Elias Katz saw the balance as a symbol of God's judgment and the dragons as a representation of the forces of Satan attempting to change the balance of the scales. ${ }^{9}$

Awareness of Christian pictorial renderings of the End of Time is certainly evident in the Jewish version of the Leipzig Mahzor, but the details are a significant departure from Christian versions. The Leipzig book combines two motifs that Christian art — in particular architectural sculpture of the Romanesque and Gothic periods - normally represents in two different thematic settings. The four creatures are associated with the Second Coming (Fig. 2), whereas the scales dominate the imagery of the Last Judgment, often — as at the portal at Bourges Cathedralaccompanied by a demon with Jewish physiognomy (Fig. 3). In the Christian context the scales are never balanced, but tend significantly to the side of the Blessed. Apart from that, the Christian four creatures follow their description in the Apocalypse (Apoc. 4:6-8) rather than that of Ezekiel. This is apparent in the arrangement of the creatures: lion and ox on the bottom and man and eagle on top. All the animals are winged and the man appears as an angel.

7 The focus on these two aspects of the messianic era is especially typical in French gothic art. In German art of the thirteenth century, most pictorial treatments of the messianic period are concentrated on the resurrection of the dead.

8 Sed Rajna (1983), 32; Narkiss's contribution to Beit-Arie (1986), 81.

9 Katz (1964), 19. 
If the Leipzig panel was fashioned after Christian models it merged two different well-known aspects of the messianic scenario: the coming of the Messiah, marked by the flanking four creatures as in Apocalypse, on the one hand, and the Last Judgment, represented by the scales, on the other. However, the story is not that simple. Several peculiarities of the Leipzig panel show us that although the designer of this iconography was certainly aware of how Christian art dealt with the messianic era, he composed an image that can only be understood against the background of Ashkenazic culture and its very particular and specific ideas concerning it.

Let us begin with the small hunting motif on the top of the upper frame: a reddish hare is running from right to left, followed slowly by a heavy, tired hound standing, rather than running, desperately sniffing the ground as if he had lost his ability to smell and to hunt. This is a variation of the traditional hunting motif as an allegory of anti-Jewish persecution ${ }^{10}$ : based on an interpretation of the Song of Songs (2:7), a female deer, standing for Israel, is pursued by a gentile hunter and his dogs representing the non-Jewish persecutor. In other examples it is a hare that attempts to escape the hunter and his dogs. ${ }^{11}$ In the Catalan Rylands Haggadah (ca. 1330; Fig. 4) the black and white dogs allude to the activity of the Dominicans, who saw

10 The marginal motif in the Leipzig panel was understood as such by Katz (1964), 19; on hunting as a metaphor for anti-Jewish persecution in medieval Jewish literature, see Epstein (1997), 21-22; on the hunting motif in Jewish art, see Schubert (1984), 119-120; Ayali (1982), 262-263.

11 Ayali (1982), 262-263. Epstein argues that the hare is rooted in a Christian defamatory symbol for the Jews, translated by the Jews into a positive image of themselves, Epstein (1997), 27. 
themselves as "Domini canes," the dogs of God, chasing the heretics. ${ }^{12}$ Another Catalan haggadah shows an inversion of the traditional hunting scene that will occur in the messianic era: an enthroned hare is being served by a dog representing Christianity (Fig. 5). ${ }^{13}$

In the Leipzig Mahzor we are not yet there. The situation has changed, though: the hare is free and the hunting hound has lost his ability; he has been weakened, but is not yet in the serving position that will mark the final stage of the messianic scenario. This variation of the hunting motif thus shows an earlier stage, one in which the preconditions for the arrival of the Messiah are about to be fulfilled.

As Israel Yuval has shown, messianic expectations were particularly acute around the year 1240, the turn of the millennium according to the Jewish calendar and, according to contemporary scholars, the belief was that the arrival of the Messiah would depend on certain preconditions. ${ }^{14}$ Detailed descriptions of the messianic erathe arrival of the Messiah, the preconditions to be fulfilled toward the coming of the Messiah - proliferated during these years. The first precondition was the restoration of Jewish political power or at least a massive Jewish presence in the Land of Israel. This idea had a particularly strong impetus as it could be understood as an inversion of and a proper response to Crusader ideology. The other way around Crusader ideology may well have been an impetus to develop the idea of restoration of political power.

The second precondition was a massive campaign of repentance. A complex system of penance was developed in the twelfth century by the Ashkenazic pietists, in

\footnotetext{
12 Schubert (1986-87), 251-252.

13 Schubert (1986-87), 250-251.

14 Yuval (1998), 110.
} 
particular by R. Judah the Pious. ${ }^{15}$ During the thirteenth century his views were slightly modified by his disciple R. Eleazar of Worms, who made the concept more applicable for a broader circle of Jews. ${ }^{16}$ The pietists combined a well-defined moral system with mysticism and highly developed eschatological interest. Penance had a key role in the general Jewish messianic expectations, especially in the pietistic concept. The ultimate aim of the pietistic penitential system was a balance of sins and virtues, for they believed that without this balance the precondition for the coming of the Messiah would not be fulfilled.

R. Judah the Pious, whose attitude was, as scholars have shown, ${ }^{17}$ quite sectarian, took up the late Antique concept of four types of penance. First penance for a sin that involuntarily confronts the sinner (tshuvat haba'ah); second penance by means of a safeguard, that is, by avoiding the object of $\sin$ (tshuvat hagader); third penance of balance by means of suffering that equals out the sin (tshuvat mishkal); and fourth penance by means of the punishment mentioned in the Bible for a particular $\sin$ (tshuvat hakatuv). ${ }^{18}$ The concept as such is not new, ${ }^{19}$ but R. Judah elaborated on it and explained that the aim of this penitential system was a balance of the divine scales of reward and punishment earned for acts of virtue and for sins. This

15 Marcus (1981), chap. 3.

16 This process was described in detail by Marcus (1981), 120-128.

17 Marcus (1981), pt. 2; Soloveichik, (1976), 330-331.

18 This terminology was developed in its final form only in the text of R. Elazar of Worms, Sefer Harokeah (1847), Hilkhot Teshuvah, par. 1-15, see Marcus (1981), 48-49; it is, however, rooted in the discussion of R. Judah, the Pious, in Sefer Hassidim (1891), par. 37- 43.

19 Babylonian Talmud, Yoma, 86a; for an English translation, see Neusner (2005), vol. 5, 336-339. 
idea of eschatological balance is the specific pietistic input into the original Talmudic concept. R. Judah the Pious and his father R. Samuel ben Kalonymus the Pious ${ }^{20}$ before him discussed these modes and the manner in which virtues can balance sins in great length and detail.

As noted, R. Judah's attitude tended to be sectarian, and some of his concepts were not applicable to broader circles of the medieval Jewish population. Among these notions was the idea of a ritual of confession to a sage, ${ }^{21}$ which was never institutionalized. R. Eleazar reinterpreted his system, eliminating the idea of confession. This and other modifications informed the bases of pietistic thought. In Marcus's words: “... despite Judah’s failure to forge German Jewry into a community of saints, R. Eleazar's adaptations of his teacher's innovations led to their incorporation into the mainstream of European Jewish piety." ${ }^{22}$ Different from R. Judah's system in which the sage plays a central role, R. Eleazar developed what Marcus calls a private penitential system, one that functions between the sinner and God. ${ }^{23}$ Although the penitential acts described by R. Eleazar were more severe than those discussed by R. Judah, the former had a much longer "afterlife," and a strong impact on most of the rabbinic literature of the centuries to come. His ideas are reflected in the writings of R. Isaac of Moses, R. Meir of Rothenburg, R. Jacob Weil, R. Israel Bruna, and others. ${ }^{24}$

20 R. Samuel the Pious, Sefer Hayir'ah, included as par. 1-13 of Sefer Hassidim (1891); for an analysis see Marcus (1981), 44-49.

21 Marcus (1981), 75-78.

22 Marcus (1981), 121.

23 Marcus (1981), chap. 8.

24 Marcus (1981), 128. 
I do not claim here that the Leipzig Mahzor reflects a pietistic worldview in any particular way. As Kurt and Ursula Schubert suggested many years ago, it rather seems that the pietists, especially R. Judah, objected to the idea of figurative art. ${ }^{25}$ Moreover, R. Judah (d. 1217) formulated his ideas during the late twelfth and the early thirteenth century, and R. Eleazar (d. 1230) was active during the early thirteenth century. Pietistic activity and writing came to an end around 1250 , and the Leipzig Mahzor was illuminated approximately sixty years later. However, after the channels were prepared by R. Eleazar, some aspects of the pietistic concepts had a significant impact on intellectual developments within German Jewry for some time after 1250 and shaped Ashkenazic thought up to the sixteenth century and beyond.

The late-thirteenth-century southern French Sefer Kol Bo, for example, reflects this process from the sectarian trend of R. Judah via the more generally applicable concepts of R. Eleazar to the adoption of pietistic elements in much wider circleseven beyond Ashkenaz — quite clearly. A highly eclectic collection of customs, halakhic material, and texts by Maimonides, on the one hand, and by R. Eleazar, on the other, the Sefer Kol Bo describes the penitential process as follows:

Rabbi Simon, the son Lakish, said on behalf of Rabbi Simon, the son of Rabbi Yosse, and the Rabbanan: it is written (Ezek. 1:8) "and hands of a man were underneath their wings"; the interpretation is: underneath the wings of the four animals; in order to receive those who repent according to the law. His right hand is stretched out to receive those who repent and to avoid that they touch the Throne of Glory as it is written (Hos. 14:2): “return Israel to God, your Lord.” Those who repent reach a location where the ministering angels are not allowed to arrive..$^{26}$

25 Schubert (1984), 70-71 relying on Sefer Hassidim, Vistinetzky (1891), par. 1625.

26 Sefer Kol Bo, Vidavsky (1997), vol. 1, 266. 
A few lines later, the text focuses on God's call for repentance:

Return Israel to God: take with you things and return to God ... I gave you my law to fulfill the precepts and to adhere to it all your days in order to remember all the good I have done to you; I warned you not to sin before me and not to follow a foreign God in your uncircumcised, unclean heart ... Return to me ... because I created penance for you ... because I loved you, son, return to the Lord with all your heart ... and this is what means "his hand is stretched out to receive those who repent," because the Holy One blessed be He embraces all those who repent and receives them as it is written (Song of Sg.: 2:6) "his right arm embraces me."27

In the text that follows this excerpt, first the four types of penance are described in detail, then a lengthy list of different kinds of sins is attached, and finally a long list of virtues or, rather, qualities that lead to virtue is added. The section concludes with a detailed description of the penitential process based on the prescriptions in R. Judah's Sefer Hasidim, ${ }^{28}$ whereas most of this text is based in various ways on the works of R. Eleazar.

This is an elaboration of a late Antique motif by means of the pietistic penitential system. Late Antique interpretations of the Ezekiel vision (Ezek. 1:8) comment on the verse "the hand of a man underneath their wings..." as the hand of God who receives the penitent. ${ }^{29}$ The text as reported in the Sefer Kol Bo combines this interpretation with the pietistic concept of penance.

27 Sefer Kol Bo, Vidavsky (1997), vol. 1, 266.

28 Sefer Kol Bo, Vidavsky (1997), vol. 1, 267-272.

29 Babylonian Talmud, Pesahim 119a, for an English version, Neusner (2005), vol. 4, 551. 
Against the background of this concept the Leipzig panel shows God on the Throne of Glory in terms of the aleph-lamed ligature, which, when the time comes, will measure the weight of the sins and virtues and accept the penitent. The Throne is indicated only by the presence of the four creatures, whose representation, as noted earlier, differs from the Christian counterparts. On the one hand, their arrangement follows their mention in Ezekiel, but, on the other, their appearance does not correspond to the biblical text. According to Ezekiel's description the overall appearance of each of them was of a man with four faces: that of a lion, an ox, an eagle, and a man. Here they appear, as was common in most artistic renderings, as separate beings. They also lack wings. The reason for this divergence from the biblical text lies in a halakhic restriction that refers in particular to the visualization of the tetramorph. A text in the thirteenth- or early fourteenth-century halakhic compilation Orhot Hayyim by R. Aaron Hakohen of Lunel, for example, quotes a responsum by R. Solomon ibn Adret of Barcelona (died c. 1310) and reads as follows: "It is forbidden to create the form of the four creatures as one figure with four faces, but creating one of them alone is not (forbidden)." After a few words of reservations concerning a figure of the man, we read a few lines later: "and that is why it is allowed to create the form of the lion, the eagle and the ox-each on its own." ${ }^{30}$ It is notable that halakhists brought up this subject at all, and it is probably an indication that artistic renderings of the visionary creatures were an issue.

In the Leipzig image the three animals - the lion, the ox, and the eagle — stand out as golden silhouettes against a blue-black background. They are framed in golden medallions, perhaps to be understood as wheels, alluding to the visionary text in Ezek. 1:15: “... and I saw wheels on the ground, one beside each of the four." The man is

30 Orhot Hayyim, Schlesinger (1902), Hilkhot Avodah Zarah 7, 232-233. 
rendered somewhat differently, as he is not shown as a silhouette, but as a colored figure wearing a rather simple hooded garment and holding, almost embracing, a book with two locks. He is not within a golden medallion, but rather is framed in red and blue. The background, not discernible in the photograph but traceable in the original, is silver. He is, therefore, as sublime as the animals, a fact that is underscored by the precious metals, either gold or silver, used in the color scheme, but he is clearly meant to be distinguished from them.

Jewish texts of various kinds, both mystical and traditionally exegetical, including those of the Ashkenazic pietists discuss the four creatures at considerable length and in great detail. ${ }^{31}$ On various occasions these discussions of the tetramorph cross another tradition that of the image of Jacob engraved in the Throne of Glory. The roots to this tradition lie in the Aramaic version of the dream of Jacob's ladder in the Jerusalem Talmud, which elaborates on the angels who climb up the ladder on the night of Jacob's dream to call their fellow angels to look at the figure whose image is engraved in the Throne. ${ }^{32}$ This motif later naturally entered the exegesis of Ezekiel's description of the Throne (Ezek. 1:26): "Above the vault over their heads there appeared, as it were, a sapphire in the shape of a throne, and exalted on the throne a form in human likeness.

There are two different traditions concerning this image of Jacob, which have been researched in depth by Eliot Wolfson. ${ }^{33}$ One explains that the human form

31 Issues of the chariot, the Throne of Glory, and the four creatures are discussed at length, e.g., by R. Eleazar of Worms, Sode Razayah, Eisenbach (2004), Hilkhot Hamerkavah.

32 Targum Pseudojonthan, Clarke (1984) Gen. 28:12.

33 Wolfson (1995). 
believed to be seated on the Throne (Ezek. 1:26) is that of Jacob, ${ }^{34}$ and the other identifies the fourth creature of the Ezekiel vision, the man, with Jacob. The medieval midrashic text Sekhel Tov deals with the story of Jacob as follows:

Rabbi Hiyya Rabba and Rab Yannai, one says: they stepped up and down on the ladder and left him; the other says: they stepped up and down in order to stay next to Jacob .... (In order to see) him whose image is engraved in the upper sphere, they stepped up and saw the fourth creature on the Throne of Glory, whose name is like his, Israel, and then they stepped down and found him sleeping.... ${ }^{35}$

Eleazar Hakallir refers to this tradition in a kerovah about the Throne of Glory to be read on New Year as early as the sixth or seventh century. Describing the four creatures, he refers to the man as "the image of the simple man (tam)," ${ }^{36}$ choosing the words from the Book of Genesis that describe Jacob as a simple or mild man sitting in the tent as opposed to the wild Esau, the hunter. The expression "simple man" is frequently explained in rabbinic literature as a hint that Jacob enjoyed a rabbinic education and became a scholar. ${ }^{37}$ Indeed the man in the Leipzig image is shown as a "simple man": the book in his arms characterizes him as scholar and the hood shown as sticking out like a hat seems to identify him as a Jew. According to both these traditional strings Jacob exhibits divine characteristics. Whether based on the

34 Halperin (1988), 121; Wolfson (1995), 8.

35 Midrash Sekhel Tov, Buber (1959), 141; see also Wolfson (1995), 8.

36 Davidson (1924), vol. 2, no. 189; Goldschmidt (1970), vol. 1, 217; Wolfson (1995), 8.

37 Bereshit Rabbah, Theodor and Albeck (1996), 63:9-10, vol. 2, 693; for an English version, see Neusner (1985), vol. 2, 360-361. 
conception of a demiurge or the Metatron, Jacob emerges in these texts as a figure with divine features.

In conclusion: What at first sight appears to be a simple reproduction and juxtaposition of common Christian messianic motifs emerges as a rather sophisticated image of the Ashkenazic pietists' penitential system. The pietistic campaign of penance prepares the world for one of the preconditions for the arrival of the Messiah: a balance between sin and virtue. This balance, measured by God himself on the Throne of Glory featuring a likeness of the divine Jacob, is reached in the image, and at the same time the hound, the non-Jewish persecutor, has lost his power and senses. Israel is free of him and able to establish its own power, another precondition for the coming of the Messiah. The messianic era will also lead to the rebuilding of the Temple, for whose prototype, the desert Tabernacle, the shekalim were originally given. 


\section{Bibliography}

R. Eleazar of Worms (1847), Sefer Harokeah (Zitomir: 1847)

R. Eleazar of Worms (2004), Sode Razayah, Hilkhot Hamerkavah, ed. R. A.

Eisenbach (Jerusalem: 2004)

Sefer Hassidim (1891), ed. Y. Hakohen Vistinetzky (Berlin: 1891)

Neusner, J., ed. (2005), The Babylonian Talmud. A Translation and Commentary (Peabody, MA: 2005)

Sefer Kol Bo (1997), ed. I. J. Vidavsky (Jerusalem: 1997)

Orhot Hayyim, Hilkhot Avodah Zarah 7 (1902), ed. M. Schlesinger (Berlin: 1902)

“Targum Pseudojonthan Gen 28:12” (1984), ed. E. G. Clarke, Targum PseudoJonathan of the Pentatuech: Text and Concordance (Hoboken: 1984).

Midrash Sekhel Tov (1959), ed. S. Buber (New York: 1959)

Bereshit Rabbah 63:9-10 (1996), eds. Y. Theodor and H. Albeck (Jerusalem: 1996)

Neusner, J. (1985), Genesis Rabbah: The Judaic Commentary to the Book of Genesis. A New American Translation (Atlanta: 1985)

Ayali, M. (1982), “Halakhah and Aggadah in Haggadah Illustrations,” Alei Siach 15/16 (1982), 262-263 (Hebrew)

Beit-Arié, M., ed. (1986) The Worms Mahzor, Jewish National and University Library, MS heb. 40781/1 (Vaduz: 1986)

Davidson, I. (1924), Thesaurus of Hebrew Poems and Liturgical Hymns from the Canonization of Scripture to the Emancipation (New York: 1924)

Epstein, M. M. (1997), Dreams of Subversion in Medieval Jewish Art and Literature (University Park, PA: 1997)

Goldschmidt, D. (1970), Mahzor Leyamim Hanora'im (Jerusalem: 1970)

Halperin, D. (1988), The Faces of the Chariot (Tübingen: 1988) 
Katz, E. (1964), Machsor Lipsiae: 68 Faksimile Tafeln der mittelalterlichen hebräischen illuminierten Handschrift aus dem Bestand der Universitätsbibliothek Leipzig (Hanau/Main: 1964)

Mackert, C., ed., Machsor Lipsiae. Virtuelle Bibliothek, Berlin, Deutsches Historisches Museum and Leipzig, Universitätsbibliothek CD ROM

Marcus, I. (1981), Piety and Society: The Jewish Pietists of Medieval Germany, (Leiden: 1981)

Raeber, J. (2003), Buchmalerei im Freiburg im Breisgau. ein Zisterzienserbrevier aus dem frühen 14. Jahrhundert: Zur Geschichte des Breviers und seiner Illumination (Wiesbaden: 2003)

Schubert, K. (1986-87), "Wikkuach-Thematik in den Illustrationen hebräischer Handschriften," Jewish Art 12/13 (1986-87), 251-252.

Schubert, K., and Schubert, U. (1984), Jüdische Buchkunst (Graz: 1984)

Sed-Rajna, G. (1983), Le Mahzor enluminé: Les voies de formation d'un programme iconographique (Leiden: 1983)

Shalev Eyni, S. (2001), “The Tripartite Mahzor,” Ph.D. dissertation, The Hebrew University of Jerusalem (2001)

Soloveichik, H. (1976), "Three Themes in the Sefer Hasidim," AJS Review 1 (1976) Voller, K. (1906), Katalog der islamischen, christlich-orientalischen, jüdischen und samaritanischen Handschriften der Unversitätsbibliothek zu Leipzig (Leipzig: 1906)

Wischnitzer, R. (1960), “The Moneychanger with the Balance: A Topic of Jewish Iconography," Erets Israel 6 (1960), 23-25 
Wolfson, E. R. (1995), “The Image of Jacob Engraved upon the Throne: Further Reflection on the Esoteric Doctrine of the German Pietists," in: ed. E. R. Wolfson, Along the Path: Studies in Kabbalistic Myth, Symbolism, and Hermeneutics (New York: 1995), 1-62.

Yuval, I. J. (1998), “Jewish Messianic Expectations Towards 1240 and Christian Reactions," in: eds. P Schäfer and M. Cohen, Toward the Millennium: Messianic Expectations from the Bible to Waco, Studies in the History of the Religions 77 (Leiden: 1998)

\section{Illustrations}

Fig. 1. Leipzig Mahzor, Universitätsbibliothek, MS V1102/I, fol. 31v, southern Germany, ca. 1310, initial decoration for the yozzer to be read on the first special Sabbath.

Fig. 2. Chartres Cathedral, western portal, ca. 1140-1150, Second Coming of Christ.

Fig. 3. Bourges Cathedral, western portal, early thirteenth century, Last Judgment.

Fig. 4. Rylands Haggadah, Manchester, John Rylands University Library, MS heb. 6, fol. 29v, Catalonia, c. 1330, marginal hunting motif.

Fig. 5. London, British Library, MS Add. 14761, fol. 30v, Catalonia or southern France, ca. 1330, Bondage in Egypt, with marginal representation of the messianic era. 